\title{
Brown rotting fungus closely related to Pseudomerulius curtisii (Boletales) recorded for the first time in South America
}

\author{
Baldoni DB ${ }^{1 *}$, Coelho $\mathrm{G}^{2}$, Jacques $\mathrm{RJS}^{3}$, Silveira $\mathrm{RMB}^{4}$, Grebenc $\mathrm{T}^{5}$ and Antoniolli $\mathrm{ZI}^{6}$ \\ ${ }^{1}$ Programa de Pós-graduação em Ciências do Solo. Universidade Federal de Santa Maria. Av. Roraima ${ }^{\circ} 1000$ - \\ Campus - Bairro Camobi - CEP: 97105-900, Santa Maria - Rio Grande do Sul, Brazil. E-mail: daianabio@ hotmail.com \\ ${ }^{2}$ Departamento de Fundamentos da Educação, Universidade Federal de Santa Maria, Brazil \\ ${ }^{4}$ Departamento de Botânica, Universidade Federal do Rio Grande do Sul, Brazil \\ ${ }^{5}$ Department of Forest Physiology and Genetics, Slovenian Forestry Institute, Slovenian \\ ${ }^{3,6}$ Departamento de Solos, Universidade Federal de Santa Maria, Brazil
}

Baldoni DB, Coelho G, Jacques RJS, Silveira RMB, Grebenc T, Antoniolli ZI 2012 - Brown rotting fungus closely related to Pseudomerulius curtisii (Boletales) recorded for the first time in South America. Mycosphere 3(5), 533-541, Doi 10.5943 /mycosphere/3/5/1

In the region of Santa Maria, Southern Brazil, we have analyzed morphologically and molecularly some interesting brown-rotting mushroom specimens closely related to Pseudomerulius curtisii. Except for minor differences in morphology and ITS sequence similarity, collections have corresponded to $P$. curtisii by basidiospore size and shape, the kind of hyphal system, the macromorphology, the slightly unpleasant pungent spicy smell turning stronger upon drying and, particularly, by the highly supported and closely related clade after phylogenetic analysis. Perhaps due the rarity in nature, morphological data are not abundant in literature and appears to be somewhat incomplete to discordant for the species, so we provide a more detailed description and illustrations from collected specimens.

Key words - Basidiomycetes - brown-rot - ITS region - Pinus elliottii - saprophytic fungi Tapinellineae.

\section{Article Information}

Received 13 August 2012

Accepted 17 August 2012

Published online 8 September 2012

*Corresponding author: Daiana Bortoluzzi Baldoni - e-mail - daianabio@hotmail.com.

\section{Introduction}

Forest environments require a complex set of organisms ensuring decomposition of available organic substrates, where fungi play an important decomposition and nutrient translocation role (Watkinson et al. 2006). Basidiomycota are the most important woody biomass decomposers. White-rot fungi have high potential for enzyme degradation of lignin and cellulose while brown-rot fungi attack preferentially cellulose compounds. Both groups are considered important organisms in recycling carbon of coniferous wood and also the main cause of decay in wooden structures (Gilbertson \& Ryvarden 1986, Zabel \& Morrell
1992, Wei et al. 2010). Brown-rot fungi have been estimated as being about $6 \%$ of wooddecaying fungi with $70 \%$ of the members belonging to Polyporaceae s. $l$., and $85 \%$ associated with gymnosperm hosts (Gilbertson 1981, Nakasone 1993).

The brown wood rot fungus Pseudomerulius has been positioned into the order Boletales, tribe Tapinellineae, and family Tapinellaceae based on recent molecular studies (Binder \& Hibbett 2004, Binder et al. 2010, Skrede et al. 2011). The genus Pseudomerulius was described with two species, $P$. aureus (Fr.) Jülich and $P$. elliottii (Massee) Jülich (Jülich 1979), and a third 
species, P. curtisii (Berk.) Redhead \& Ginns, was later included (Redhead \& Ginns 1985). These species are closely related to Leucogyrophana and Serpula, but differ in having much smaller and narrower spores and basidia. $P$. curtisii is difficult to miss due to its vivid golden-yellow colour. The geographic distribution ranges from North and Central Americas - USA, Canada, Hawaii, Mexico, Dominican Republic (Ginns \& Lefebvre 1993, Gilbertson \& Hemmes 1997, Mora \& Garza 1997); East Asia - Korea, Japan, Thailand (Takahashi et al. 2005, Quang et al. 2006, Chandrasrikul et al. 2011); Oceania Australia, including Tasmania (Ginns 1971, Fuhrer 2005, Ratkowsky \& Gates 2005). Previous phylogenetic analyses indicated its close relation to Pseudomerulius aureus (Fr.) Jülich, Tapinella panuoides (Batsch) E.-J. Gilbert and Bondarcevomyces taxi (Bondartsev) Parmasto (Larsson et al. 2004, Binder \& Hibbett 2006) although the low number of available sequences has not enabled any intraspecific variation study to date.

In general, wood-decaying fungi have great potential in biotechnology, industry, and pharmaceutical uses. Species of Pseudomerulius are known to have medicinal properties such as producing a series of p-terphenyl derivatives that act as free-radical scavengers (Quang et al. 2006, Zhou et al. 2010). In addition, extracts can protect cultured neuronal cells against glutamate neurotoxicity, oxidative damage of supercoiled DNA or act as general antioxidant (Lee et al. 2003, Liu 2006, Zhou et al. 2010).

Pseudomerulius curtisii is unreported from South America. However, basidiomes suspected to be this species were recently found in Southern Brazil. The present study aims to elucidate the taxonomic position of the Brazilian material from a morphological study and from molecular data.

\section{Methods}

\section{Fungal material collections and morphological characterization}

Basidiomes with poroid or similar hymenophores (merulioid, irpicoid or poroidraduloid) have been regularly collected from 2007-2012 from native and cultivated ornamental/experimental areas with Pinus spp. or Eucalyptus spp. in the municipality of Santa Maria, central region of Rio Grande do Sul State, Southern Brazil. Main collection sites were the cultivated areas at FEPAGRO/Florestas - Fundação Estadual de Pesquisa Agropecuária and Campus of UFSM (Federal University of Santa Maria) following other local Basidiomycota studies (Coelho et al. 2006, Andreazza et al. 2008, Sulzbacher et al. 2010).

Each collection was briefly described in situ, photographed, and carefully collected in plastic pots or absorbent paper for isolation, laboratory analysis, and preservation. The type of wood rot was inferred from the substrate. Diploid mycelium was isolated from sporocarps and cultivated according to Brundrett et al. (1996) and is stored in the Bank of Fungi of Laboratory of Soil Biology and Environmental Microbiology Prof. Marcos Rubens Fries under the voucher numbers given in Table 1. Preserved specimens are deposited at ICN (Universidade Federal do Rio Grande do Sul, Brazil) and SMDB (Universidade Federal de Santa Maria, Brazil) Herbaria. Morphological features were assessed from fresh basidiomes through handmade sections, under a stereoscopic microscope (up to $40 \mathrm{x}$ magnification) or Hund H500 microscope (magnification up to 1000x). A Munsell Soil Color Chart (1994) was used as reference to the colour names. $\mathrm{KOH} 5 \%$ plus aqueous phloxine or drops of Melzer's reagent were used for liquid mounting media and chemical tests. Measurements were statistically analyzed using EXCEL ${ }^{\circledR}$ (Microsoft Office $\AA$ 2003) and abbreviations presented follow Coelho (2005): $D_{(m)}=$ diameter (average); $L_{m} \times W_{m}=$ av. Length $\times$ av. width \pm standard degree; $Q=$ quotient of length/width; $Q_{m}=$ av. quot.; $Q r=$ quot. range; $n / n=\mathrm{n}$ measurements from $/ \mathrm{n}$ basidiomes. Basidiospore shapes are classified based on the $Q$ range intervals of Stalpers (2007).

\section{Molecular analysis}

DNA was extracted from parts of the basidiomes using a DNeasy Plant Mini Kit (Qiagen, São Paulo, Brazil). The complete ITS region in nrDNA (ITS1-5.8S-ITS2) was amplified with primers ITS1 and ITS4 (White et al. 1990). Reactions were adapted for 
Table 1 Specimens of fungi included in this study. In bold, GenBank accession numbers of sequences obtained from Pseudomerulius curtisii, Santa Maria, RS, Brazil.

\begin{tabular}{|c|c|c|c|}
\hline Species & Strain & Locality & $\begin{array}{l}\text { GenBank } \\
\text { accession number }\end{array}$ \\
\hline Athelia arachnoidea & CBS: 418.72 & Netherlands & GU187504 \\
\hline Athelia epiphylla & CFMR: FP-100564 & USA & GU187501 \\
\hline Bondarcevomyces taxi & Dai2524 & China & DQ534575 \\
\hline Coniophora arida & CFMR: FP-104367 & USA & GU187510 \\
\hline Coniophora cerebella & 8 & USA & GU187513 \\
\hline Coniophora marmorata & P 307 & United Kingdom & AJ518880 \\
\hline Coniophora marmorata & MUCL: 31667 & Belgium & GU187515 \\
\hline Coniophora olivacea & MD-264 & USA & AM747534 \\
\hline Coniophora prasinoides & MA-Fungi 19417 & USA & AJ419197 \\
\hline Coniophora puteana & MUCL:1000 & Germany & GU187521 \\
\hline Jaapia argillacea & CBS:252.74 & Netherlands & GU187524 \\
\hline Leucogyrophana arizonica & CFMR:RLG-9902 & USA & GU187527 \\
\hline Leucogyrophana mollusca & CFMR:L-10277 & USA & GU187525 \\
\hline Leucogyrophana mollusca & P 263 (14167) & Sweden & AJ419914 \\
\hline Leucogyrophana mollusca & P 265 (G 201) & - & AJ419915 \\
\hline Leucogyrophana olivascens & CFMR:HHB-11134 & USA & GU187532 \\
\hline Leucogyrophana pinastri & MA-Fungi 7924 & Spain & AJ419214 \\
\hline Leucogyrophana pinastri & P 273 (G 117) & Germany & AJ419916 \\
\hline Leucogyrophana pinastri & P 275 (G 202a) & - & AJ419917 \\
\hline Leucogyrophana romellii & DAOM 148653 & USA & GU187530 \\
\hline Leucogyrophana romellii & CFMR:T-547 & Canada & GU187529 \\
\hline Pseudomerulius aureus & CFMR:FP-103859 & USA & GU187534 \\
\hline Pseudomerulius curtisii & REH8912 & Australia & GU187533 \\
\hline Pseudomerulius curtisii & DJL-DR-4 & Dominican Republic & GU187536 \\
\hline Pseudomerulius curtisii & DBB1 & Brazil & JN974314 \\
\hline Pseudomerulius curtisii & DBB34 & Brazil & JX157585 \\
\hline Serpula lacrymans & REG 383 & - & GU187542 \\
\hline Serpula himantioides & CFMR: RLG-12941 & USA & GU187547 \\
\hline Tapinella atrotomentosa & $122 / 98$ & USA & GU187550 \\
\hline Tapinella atrotomentosa & $78 / 97$ & USA & GU187549 \\
\hline Tapinella panuoides & JLM 1752 & USA & GU187551 \\
\hline Tapinella panuoides & MB05-019 & USA & GU187548 \\
\hline
\end{tabular}

optimal amplification as follows: initial denaturation cycle at $94^{\circ} \mathrm{C}$ for $2 \mathrm{~min}, 40$ cycles of denaturation at $94{ }^{\circ} \mathrm{C}$ for 1 min., annealing at $50{ }^{\circ} \mathrm{C}$ for $1 \mathrm{~min}$., and extension at $72{ }^{\circ} \mathrm{C}$ for $1 \mathrm{~min}$. and $30 \mathrm{~s}$., plus one final extension cycle at $72{ }^{\circ} \mathrm{C}$ for $7 \mathrm{~min}$. Reactions were performed in a total volume of $25 \mu \mathrm{L}$, with the components: $10 \mathrm{ng}$ of template DNA, $1 \mu \mathrm{mol}$ of each primer, $20 \mathrm{mM}$ Tris- $\mathrm{HCl}(\mathrm{pH} \mathrm{8.4)}$ and $50 \mathrm{mM}$ reaction buffer, $2 \mathrm{mM} \mathrm{MgCl}_{2}, 0,2 \mathrm{mM}$ dNTP, 2,5 unit of Taq DNA polymerase
(Invitrogen, São Paulo, Brazil) and ultrapure $\mathrm{H}_{2} \mathrm{O}$.

After the amplification, electrophoresis was performed to check the amplification in $1.5 \%$ agarose gel and $1 \mathrm{X}$ TBE buffer $(90 \mathrm{mM}$ Tris-borate, $2 \mathrm{mM}$ EDTA, $\mathrm{pH}$ 8.0). DNA was stained with Blue green Loading Dye I ${ }^{\circledR}$ (LGC Biotecnologia, Cotia, Brazil) and observed in ultraviolet light. PCR products were purified with the Gen Elute PCR clean-up Kit (Sigma, Saint Louis, USA) following manufacturer's 


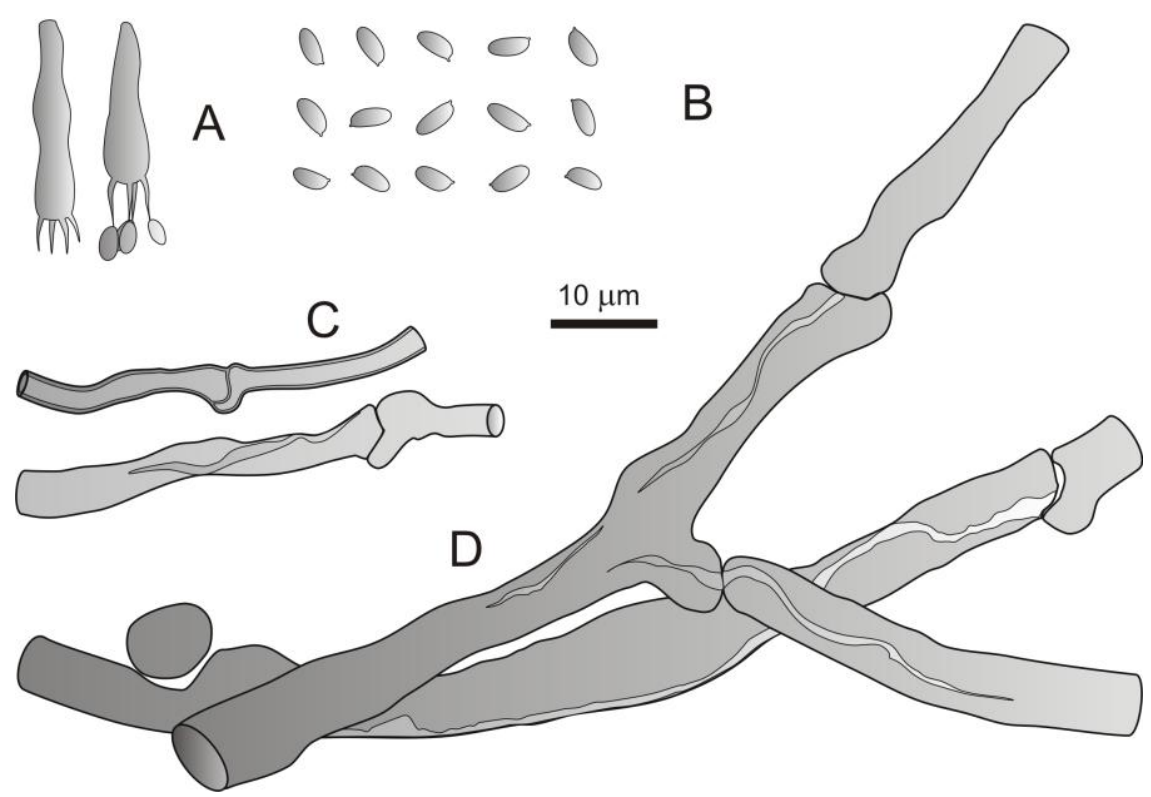

Fig. 1 - Microscopical structures of Pseudomerulius collections from Brazil. A Basidia. B Ellipsoid basidiospores. C Tramal generative hyphae presenting thin to thickened walls with irregular lumen. D Contextual generative hyphae (ICN 139783).

instructions and sequencing was carried out in Mega BACE sequencer 500 (Amersham Biosciences).

Sequenced fragments were analyzed using the program Staden Package 2.0.0b (Staden et al. 2003). Sequences were deposited in GenBank under the accession numbers given in Table 1.

Selected closely related sequences for phylogenetic relationship analysis from the Boletales were retrieved from the GenBank database (Table 1) on 11 March 2012. Sequences were aligned with MAFFT 6.0 program (Katoh et al. 2002) using L-ins-i algorithm. A GTR+I nucleotide substitution model was used after the ModelTest (Posada 2006) run. The Maximum Likelihood (ML) method analyses were performed using PhyML 2.45 program (Guindon \& Gascuel 2003) with 1000 bootstraps, I and $G$ invariants were estimated. Tree was drawn and modified in Mega 5.0 (Tamura et al. 2011).

The Neighbor Joining (NJ) and Maximum Parsimony (MP) (established with the same model used to construct the ML tree) methods analyses were performed in MEGA 5.0 (Tamura et al. 2011) and 1000 bootstrap replicates were used in all reconstructions. Sequences from Athelia arachnoidea (GU187504), A. epiphylla (GU187501), Jaapia argillacea (GU187524) were used as outgroup.

\section{Results}

We collected seven samples belonging to the genus Pseudomerulius. All collections showed high morphological similarity with Pseudomerulius curtisii as described by Redhead \& Ginns (1985).

\section{Summary description of morphological characters of Pseudomerulius curtisii related collections from Brazil Figs. 1-2}

Basidiome annual, effuse-reflexed to pileate, gregarious, flexible, fleshy, watery, breakable, firm upon drying, up to $65 \times 52 \times$ $12 \mathrm{~mm}$, with an unpleasant, pungent and spicy smell resembling pet food or a strong odor of cinnamon that intensifies after desiccation. Pileus dimidiate, flabelliform to spatulate, fleshy; pilear surface yellow (8/6-7/8 2.5Y), with shades of olive brown (4/3-4/4 2.5Y) when bruised; pileus surface cottony to felty, wavy; margin indistinct, rounded, lobed. Hymenophore irregularly lamellate to almost merulioid, formed by strongly corrugated gills, waxy, vivid coloured, yellow (8/6-7/8 10YR) to brownish yellow (6/6-6/8 10YR) to dark olive brown (3/3 2.5Y) when bruised; folds as corrugated or irregular lamellae, radially oriented, occasionally forked, more straight and shallow next to the margin, soon becoming irregular to wavy and deeper at maturity thicker next to the substrate, thinning towards 


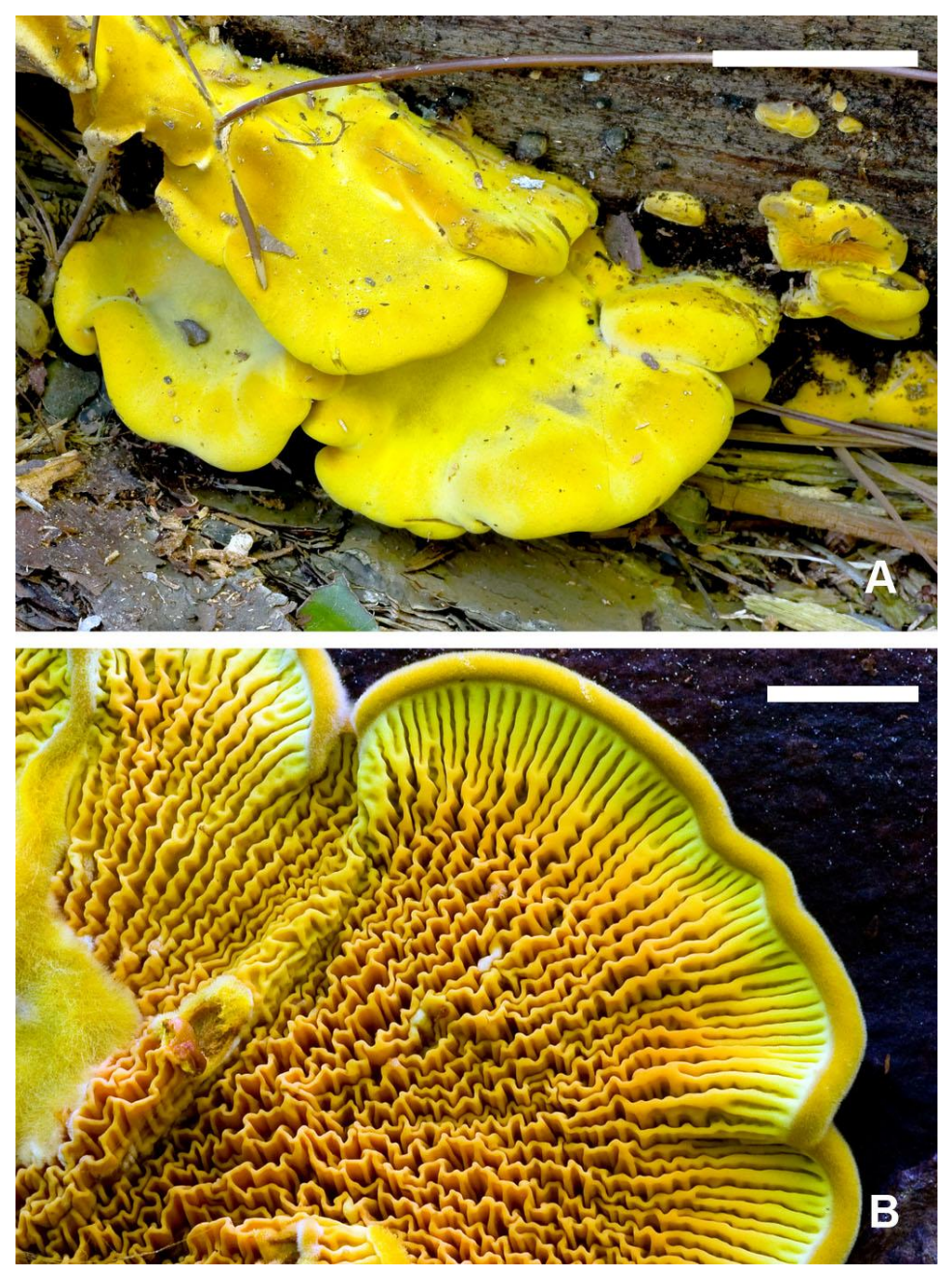

Fig. 2 - Basidiomes of Pseudomerulius curtisii related specimens on decayed wood of Pinus sp. A Pileus, upper view (DBB 1, SMDB 13.701), Scale bar $=2 \mathrm{~cm}$. B Pileus, lower view showing folded lamellae (ICN 139784), bar $=0.5 \mathrm{~cm}$.

the margin, $(0.5-) 1(-2) \mathrm{mm}$ in width, $P_{m}=$ $1.21, n=61 / 1$; dissepiments thick, glabrous, smooth; margin yellow (8/6-7/8 10YR), forming a sterile growing zone, felty, slightly incurved on hymenophore, fragile, easily bruised. Fold layer concolorous to the hymenophore, up to $3 \mathrm{~mm}$ thick. Context yellow (8/6-8/8 2.5Y), paler than the folds, thick, up to $10 \mathrm{~mm}$ thick, homogeneous, fleshy, easily to macerate, with a slightly darker cortex formed by the felty, pilear surface.

Hyphal system monomitic. Tramal generative hyphae clamped, whitish opaque, thin to usually thick-walled, with a narrow, sinuous, and discontinuous lumen, often branched, sinuous in outline, swelling in $\mathrm{KOH}$, (1.8-)2.8-6.8(-8.4) $\mu \mathrm{m}$ diam., $D_{m}=4.2, n=62 / 1$. Contextual generative hyphae clamped, whitish opaque, thick-walled, sinuous in outline, almost solid, with a narrow, sinuous, and with a discontinuous lumen, sometimes very enlarged, often branched, (4-)4.4-10.8(12) $\mu \mathrm{m}$ diam., $D_{m}=6.8, n=62 / 1$, narrowing and elongating to form a felty pileus surface.

Hymenophore with basidia clavate, four-sterigmate, (12.8-) 14.4-17.6(-20) $\times(3.2-$ )3.6-4(-4.4) $\mu \mathrm{m}, L_{m} \times W_{m}=16.1 \pm 1.91 \times 3.67$ $\pm 0.35, Q_{r}=2.91-6.00, Q_{m}=4.40 \pm 0.62, n=$ 61/1. Basidiospores ellipsoid, narrowly ellipsoid to subcylindrical, abundant, moderately thick-walled, indextrinoid, often guttulate, 3.2-4(-4.4) $\times 1.6-1.8(-2) \mu \mathrm{m}, L_{m} \times W_{m}=3.6 \pm$ $0.38 \times 1.79 \pm 0.11, Q_{r}=1.74-2.50, Q_{m}=2.04 \pm$ $0.20, n=60 / 1$; hyphidia and cystidia not seen.

Associated wood rot: brown.

Known geographic distribution - From North and Central Americas to East Asia, and Oceania. 


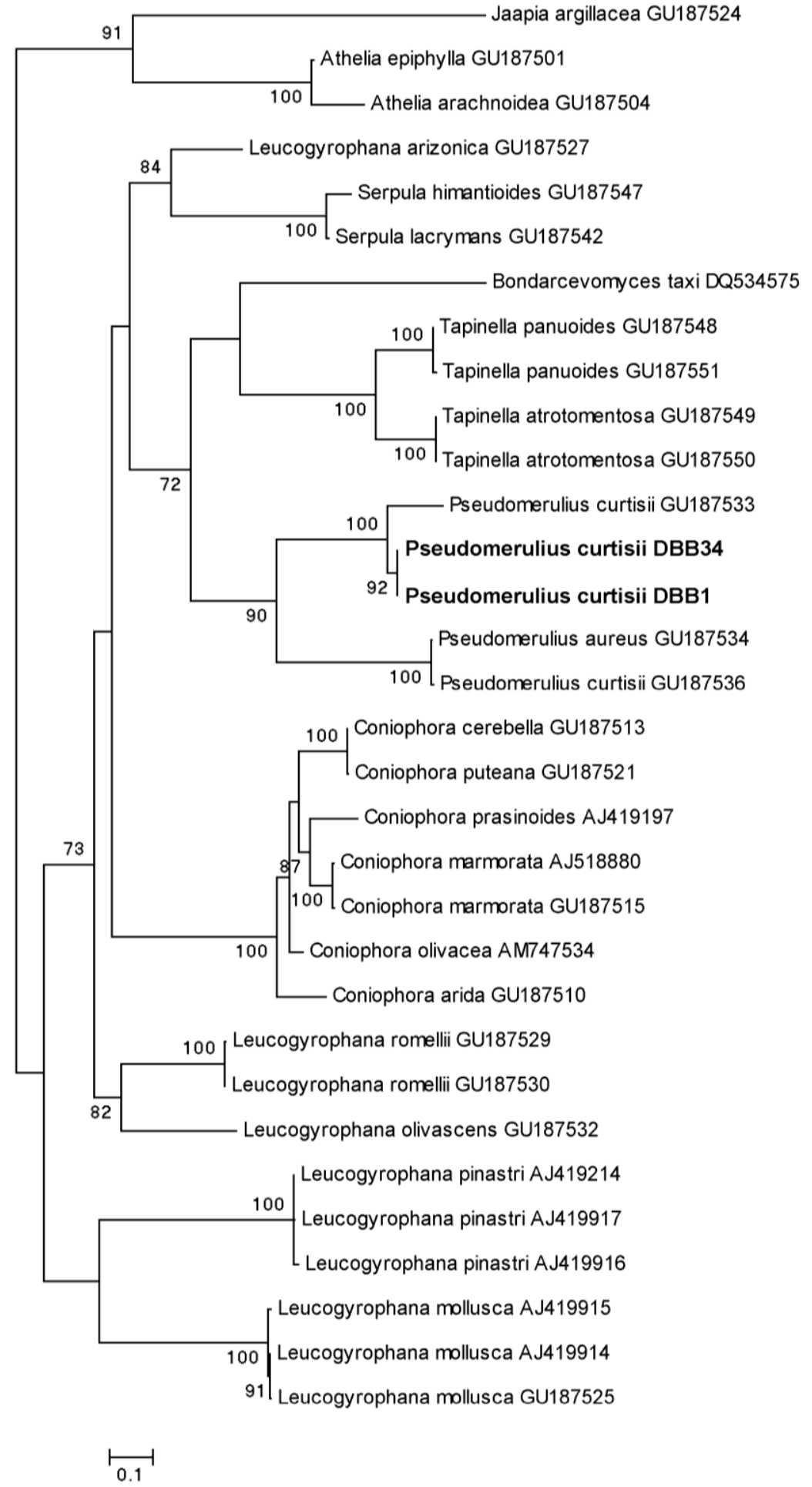

Fig. 3 - Phylogenetic reconstruction of the Pseudomerulius curtisii obtained from ITS1-5.8S-ITS2 sequences. Bootstrap values (in \%) are from maximum likelihood (ML) analyses (1000 bootstraps). Only topologies with bootstrap values of at least 50\% are shown. Sequences from Athelia arachnoidea, A. epiphylla and Jaapia argillacea were used as outgroup.

Substrate - growing on fallen decayed wood of P. elliottii and other Pinus spp. over forest soil; more common in autumn, sometimes in wet summer; rare in occurrence in the study area.
Specimens examined - Brazil, Rio Grande do Sul, Santa Maria, Campus/UFSM, on Pinus elliottii, 17 Dec 2007, leg. G. Coelho, $\mathrm{N}^{\circ} \mathrm{GC}$ 653-4 (ICN 139783); on Pinus sp., 21Dec 2007, NºC 654-3 (ICN 139784); on $P$. 
elliottii, 15 Jan 2008, $\mathrm{N}^{\circ} \mathrm{GC}$ 662-2 (ICN 139785); on P. elliottii 19 Jan 2008, $\mathrm{N}^{\circ} \mathrm{GC}$ 663-2 (ICN 139786); on Pinus sp., 29 Jan 2008, N ${ }^{\circ} \mathrm{GC}$ 665-1 (ICN 139787); FEPAGRO, on Pinus sp.,3 Jan 2011, leg. G. Coelho \& D.B. Baldoni, NoDBB 1 (SMDB 13.701); on UFSM, Pinus sp., leg. G. Coelho \& D.B. Baldoni, 5 Jan 2012, N DBB 34 (SMDB 13.702).

The NJ, MP and ML analyses of the same sequence dataset yielded similar phylogenetic trees (Fig. 3). The analyzed sequences from Brazil formed a well-supported uniform clade, closely related to $P$. curtisii (GU187533), from Australia.

\section{Discussion}

As shown by Binder et al. (2010) Pseudomerulius is in family Tapinellineae with Coniophoraceae as the sister clade and Serpulaceae, represented in our tree by Serpula lacrymans and S. himantioides, as a basal group. We have confirmed the close relation of Pseudomerulius with Leucogyrophana. The latter genus appeared polyphyletic.

The Pseudomerulius collections from Brazil showed very similar morphology when compared with the original description of $P$. curtisii and those of its synonyms in literature, but with some minor differences depending on the author, in particular: the thickness of the basidiospore and hyphae walls, hyphae diameter, and the presence of slightly unpleasant pungent spicy smell turning stronger upon drying. Our mature fresh collections were microscopically mainly built by a monomitic hyphal system with clamped and almost solid hyphae usually having a sinuous lumen; they were also characterized by producing hyaline, indextrinoid, and narrowly-ellipsoid to subcylindrical basidiospores. The macromorphological features including yellow-lemon to golden yellow vivid colours in cartilaginous, pileate basidiomes and the strong radially folded hymenophores (lamellar-corrugated to merulioid type) were shared, making $P$. curtisii and our collections readily recognizable in nature and very attractive. Other macromorphologically related species can be separated from our collections and original $P$. curtisii, namely $P$. aureus (Fr.) Jülich, by presenting effuse to a few reflexed basidiomes and hyphae relatively narrower, even also presenting merulioid hymenial surface (Ginns 1998), and Tapinella panuoides, by having paler (whitish to brownish yellow) true lamelar basidiomes, yet reflexed to pileate (Gilbertson 1981). Bessete et al. (2000) reported $P$. curtisii under the nomenclatural synonym Meiorganum curtisii (Berk.) Singer, Garcia \& Gomez among the North American boletes as having dextrinoid basidiospores. Presence of dextrinoid reaction of basidiospores was not confirmed in our analysis of fresh mature specimens and that of some other authors under the same name (Gilbertson \& Hemmes 1997, Gilbertson et al. 2002) or under different names (Ginns 1969, as Merulius crassus).

Molecular analysis of species within Pseudomerulius separated well the analyzed collections from Brazil. A well supported clade $(92 \%)$ and only $95 \%$ similarity with the Australian P. curtisii sample (GU187533) may indicate the presence of a cryptic species or highly separated geographic variety existing in South America (Brazil). The collection of Pseudomerulius curtisii GU187536 clustering in $P$. aureus clade may represent a misidentification.

Pseudomerulius curtisii, to which the Brazilian collections fit best, usually grows hidden at the base or along the sides of decayed logs in the study area. Perhaps due this fact, it has been considered as rare in the world, even though obvious in appearance (with bright yellow basidiomes and minutely rugose gills) and strikingly in its odor of cinnamon (Lee et al. 2009). The species was previously unknown in South America and our analysis indicate a close relationship of Brazilian collections with $P$. curtisii, yet with some minor differences, which would need further detailed analysis and may potentially result in a new, yet undescribed taxon from this continent.

Based on literature and internet reviews, we have found a scarcity of biogeographical, molecular, and biochemical data about the species in focus; the present study represents a contribution to the better knowledge of the species and to local future studies on soil formation and decomposition by wood- decomposing agents of fungal diversity in cultivated and native forests ecosystems. 


\section{Acknowledgements}

The authors wish to acknowledge the National Council for Scientific and Technological Development $(\mathrm{CNPq}-$ Brazil by the grants process 490490/2010-7, Call $\mathrm{MCT} / \mathrm{CNPq} \mathrm{n}^{\circ} 53 / 2010$ and the Coordination for the Improvement of Higher Education Personnel (CAPES - Brazil) for their financial support. The work was co-financed by the Brazil - Slovenia bilateral project (BI-BR/1113-005).

\section{References}

Andreazza R, Antoniolli ZI, De Oliveira VL, Leal LT, Moro CAJR, Pieniz S. 2008 Ocorrência de associação micorrízica em seis essências florestais nativas do estado do Rio Grande do Sul. Ciência Florestal. 18, 339-346.

Bessette AE, Roody WC, Bessette AR. 2000 North American Boletes: A color guide to the fleshy pored mushrooms. Syracuse University Press, Syracuse, New York. 396 p.

Binder M, Hibbett DS. 2004 - Toward a Global Phylogeny of the Boletales. http://www.clarku.edu/faculty/.../ boletales.../Boletales_Target_list_2004. doc. -2008.

Binder M, Hibbett DS. 2006 - Molecular systematics and biological diversification of Boletales. Mycologia 98, 971-983.

Binder M, Larsson KH, Matheny PB, Hibbett DS. 2010 - Amylocorticiales ord. nov. and Jaapiales ord. nov.: early diverging clades of agaricomycetidae dominated by corticioid forms. Mycologia 102, 865-880.

Brundrett M, Bougher N, Dell B; Grove T, Malajczuk N. 1996 - Working with Mycorrhizas. In: Forestry and Agriculture. ACIAR Monograph No. 32. Canberra, Australia, Pirie Printers. 373p.

Chandrasrikul A, Suwanarit P, Sangwanit U, Lumyong S, Payapanon A, Sanoamuang N, Pukahuta C, Petcharat V, Sardsud U, Duengkae K, Klinhom U, Thongkantha S, Thongklam S. 2011 Checklist of Mushrooms (Basidiomycetes) in Thailand. Office of Natural Resources and Environmental Policy and Planning, Bangkok, Thailand. 448 p.

Coelho G. 2005 - A Brazilian new species of Auriporia. Mycologia 97, 266-277.

Coelho G, Silveira RMB, Rajchenberg M. 2006 - A new Gloeoporus species growing on bamboo from southern Brazil. Mycologia 98, 821-827.

Fuhrer B. 2005 - A Field Guide to Australian Fungi. Bloomings Books.

Gilbertson RL. 1981 - North American woodrotting fungi that causes brown rots. Mycotaxon 12, 372-416.

Gilbertson RL, Hemmes DE. 1997 - Notes on Hawaian Coniophoraceae. Mycotaxon 64, 427-442.

Gilbertson RL, Ryvarden L. 1986 - North American polypores. Abortiporus Lindtneria. Fungiflora, Oslo, 1, 1-433.

Gilbertson RL, Bigelow DM, Hemmes DE, Desjardin DE. 2002 - Annotated check list of wood-rotting Basidiomycetes of Hawaii. Mycotaxon 82, 215-239.

Ginns JH. 1969 - The genus Merulius II. Species of Merulius and Phlebia proposed by Lloyd. Mycologia 61, 357-372.

Ginns JH. 1971 - The genus Merulius IV. Species proposed by Berkeley, by Berkeley and Curtis, and by Berkeley and Broome. Mycologia 63, 219-236.

Ginns JH. 1998 - Genera of the North American Corticiaceae sensu lato. Mycologia 90, 1-35.

Ginns JH, Lefebvre, MNL. 1993 - Lignicolous corticioid fungi (Basidiomycota) of North America. Systematics, distribution, and ecology. Mycological Memoirs 19, 1-247.

Guindon S, Gascuel O. 2003 - PhyML: "A simple, fast, and accurate algorithm to estimate large phylogenies by maximum likelihood." Systematic Biology 52, 696-704.

Katoh K, Misawa K, Kuma K, Miyata T. 2002 - MAFFT: a novel method for rapid multiple sequence alignment based on fast Fourier transform. Nucleic Acids Research 30, 3059-3066.

Larsson KH, Larsson E, Kõljalg U. 2004 High phylogenetic diversity among corticioid homobasidiomycetes. Mycological Resourch 108, 983-1002. 
Lee IK, Yun BS, Kim JP, Kim WG, Ryoo IJ, Oh S, Kim YH, Yoo ID. $2003-p$ Terphenyl curtisians protect cultured neuronal cells against glutamate neurotoxicity. Planta Medica 69, 513-517.

Lee IK, Jung JY, Kim YS, Rhee, MH, Yun BS. 2009 - p-Terphenyls from the fruiting bodies of Paxillus curtisii and their antioxidant properties. Bioorganic \& Medicinal Chemistry 17, 4674-4680.

Liu JK. 2006 - Natural terphenyls: developments since 1877. Chemical Reviews 106, 2209-2223.

Mora RN, Garza RV. 1997 - Los macromicetos de la Sierra de Nanchititla. Polibotánica 5, 21-36.

Munsell Soil Color Charts. 1994 - Macbeth Division of Kollinorgen Instruments Corporation.

Nakasone KK. 1993 - Biodiversity and coarse woody debris in southern forests. Proceedings of the Workshop on Coarse Woody Debris in Southern Forests: Effects on Biodiversity. Athens, GA. 18-20, 35-42.

Posada D. 2006 - ModelTest Server: a webbased tool for the statistical selection of models of nucleotide substitution online. Nucleic Acids Research 34, W700-W703.

Quang DN, Hashimoto T, Asakawa Y. 2006 Inedible mushrooms: a good source of biologically active substances. The Chemical Record 6, 79-99.

Ratkowsky DA, Gates GM. 2005 - An inventory of macrofungi observed in Tasmanian forests over a six-year period. Tasforests 16, 153-168.

Skrede I, Engh IB, Binder M, Carlsen T, Kauserud H, Bendiksby M. 2011 Evolutionary history of Serpulaceae (Basidiomycota): molecular phylogeny, historical biogeography and evidence for a single transition of nutritional mode. BMC Evolutionary Biology 11, 230-241.

Staden R, Judge DP, Bonfield JK. 2003 Analysing sequences using the Staden package and EMBOSS. Introduction to Bioinformatics. A Theoretical and Practical Approach. Eds. Stephen A. Krawetz and David D. Womble. Human
Press Inc., Totawa, NJ 07512. pp. 393410.

Stalpers J. 2007 - Aphyllophoroid Russulales database. The resupinate Russulales species bank. http://www.cbs.knaw.nl/ russulales/DefaultPage.aspx. - 2008.

Sulzbacher MA, Cortez VG, Coelho G, Jacques RJS, Antoniolli ZI. 2010 Chondrogaster pachysporus in a Eucalyptus plantation of southern Brazil. Mycotaxon 113, 377-384.

Takahashi KH, Tuno N, Kagaya T. 2005 Abundance of mycophagous arthropods present on different species of fungi in relation to resource abundance at different spatial scales. European Journal of Entomology 102, 39-46.

Tamura K, Peterson D, Peterson N, Stecher G, Nei M, Kumar S. 2011 - MEGA5: Molecular evolutionary genetics analysis using maximum likelihood, evolutionary distance, and maximum parsimony methods. Molecular Biology and Evolution 28, 2731-2739.

Watkinson S, Bebber D, Darrah P, Fricker M, Tlalka M, Boddy L. 2006 - The role of wood decay fungi in the carbon and nitrogen dynamics of the forest floor. In: Gadd G.M. (Ed.) Fungi in Biogeochemical Cycles. Cambridge University Press, UK, pp. 151-181.

Wei D, Houtman CJ, Kapich AN, Hunt CG, Cullen D, Hammel KE. 2010 - Laccase and its role in production of extracellular reactive oxygen species during wood decay by the brown rot Basidiomycete Postia placenta. Applied and Environmental Microbiology 76, 2091-2097.

White TJ, Bruns T, Lee S, Taylor J. 1990 Amplification and direct sequencing of fungal ribosomal RNA genes for phylogenetics. In: Innis, Innis MA; Gelfand DH. (Eds.) PCR protocols. A guide to methods and applications. Academic Press, San Diego. p. 315-322.

Zabel RA, Morrell JJ. 1992 - Wood Microbiology: decay and its prevention. Academic Press, California.

Zhou ZY, Liu JK. 2010 - Pigments of fungi (macromycetes). Natural Product Reports. The Royal Society of Chemistry 27, 1531-1570. 